DOI https://doi.org/10.30525/978-9934-588-90-7-41

\title{
ПРОБЛЕМАТИКА ВИЗНАЧЕННЯ ПОНЯТТЯ «ТЕКСТ» В НАУКОВИХ ДОСЛІДЖЕННЯХ
}

\author{
Лісовська А. О. \\ кандидат філологічних наук, \\ дочент кафедри мовної підготовки \\ Одеський державний університет внутрішніх справ \\ м. Одеса, Україна
}

Поняття «текст» як продукт усного чи письмового мовлення не знайшло остаточного однозначного визначення у сучасній лінгвістиці як унаслідок існування різних текстових форм й типів, так i в силу багатоплановості його структурно-семантичної і комунікативно-змістової організації. На думку О. С. Кубрякової, зведення всієї безлічі текстів в єдину систему так само складно, як і виявлення за всією безліччю такої низки достатніх та необхідних рис, яка була б обов'язковою для визнання тексту, у термінах категорії класичного, арістотелевого типу [9].

У мовознавстві текст розглядається як продукт мовлення. За визначенням I. Р. Гальперіна текст - це «твір мовотворчого процесу, який володіє завершеністю, об'єктивований у вигляді письмового документу, ... що складається 3 назви (заголовка) й низки особливих одиниць (надфразових єдностей), об'єднаних різними типами лексичного, граматичного, логічного, стилістичного зв'язку, що має певну спрямованість $\mathrm{i}$ прагматичну установку» [6, с. 17]. Це широковідоме і часто цитоване визначення вказує на такі важливі характеристики тексту, як цілісність, зв'язність елементів і функціональну спрямованість. Насправді текст як продукт мовленнєво-мисленнєвої діяльності може бути результатом не тільки письма, але й говоріння, бути як письмовим, так і усним, тобто зафіксованим оптично, акустично або якось інакше. При цьому просторова фіксація є не випадковістю, а засобом передачі повідомлення автором [8, с. 64]. Багато лінгвістів вважає, що текст як комунікативний феномен, орієнтований на специфіку певного роду діяльності - це будь-який мовленнєвий твір будь-якого формату. Водночас текст розуміється як мовленнєва реалізація цілісного творчого авторського задуму i комунікативна одиниця найвищого рівня, реалізована як в письмовому, так і в усному мовленні.

Психолінгвістичний підхід передбачає вивчення тексту як складного семантичного утворення якому притаманні ряд специфічних характеристик. 3 точки зору комунікативної лінгвістики текст розглядається як одиниця комунікації, якої властиві цілісність, семантична зв'язність, 150 
емотивність (текст відображає емоційно-оцінне ставлення автора до дійсності). Важливими на нашу думку властивостями тексту $є$ його можлива креолізованість (текст може містити елементи інших семіотичних систем) і прецедентність (наявність в тексті елементів попередніх текстів). Текст має внутрішню структуру - синтаксичну (на рівні складного синтаксичного цілого і пропозиції), композиційну і логічну, й певну прагматичну настанову. Текст має у собі уявлення про свою референтну основу (затекст) та, крім явного, містить неявний зміст (підтекст) [3, с. 114]. Згідно В. П. Беляніну, текст - це «феномен реальної дійсності й спосіб відображення дійсності, побудований за допомогою елементів системи мови», це продукт мовлення, «детермінованого потребами спілкування» $[4$, с. 9$]$.

3 точки зору лінгвістики тексту текст розуміється як «певна (закінчена) послідовність речень, зв'язаних за змістом одне 3 одним у рамках загального задуму автора» $[12$, с. 6]. У цьому визначенні головними критеріями об'єкта, що характеризується, виступають завершеність, зв'язність і наявність авторського задуму. Лінгвістика тексту часом зближується із дискурсивним підходом до тексту і акцентує аспекти породження та сприйняття тексту. В такому випадку текст визначається як «продукт, породжений мовною особистістю та адресований мовній особистості», який «є мертвим без акту пізнання» [13, с. 106-107].

Семіотичний підхід до тексту передбачає більш широке трактування його як осмисленої послідовності будь-яких знаків, будь-якої форми комунікації, включаючи обряд, танець, ритуал і т.п. [1, с. 507]. Знак тут матеріально виражена заміна предметів, явищ, понять в процесі обміну інформацією в колективі $[11$, с. 4$]$. Інакше кажучи, текст культури може бути виражений як природною мовою, так і мовами різних видів мистецтв. Текстом в широкому сенсі, на думку Г. І. Богіна, може вважатися будьякий матеріальний предмет, у генезисі якого брала участь людська суб'єктивність: це може бути одяг, живописне полотно, витвір архітектури [5]. Крім того, в рамках цього підходу, дослідники акцентують потенційну семіотичну неоднорідність тексту, стверджуючи, що його рівноправними складовими можуть бути вербальні одиниці і невербальні елементи (в тому числі піктографічні, іконічні повідомлення-зображення), залучені в вербальний текст з метою зокрема, інтенсифікації процесу передачі сенсу.

Як формально-стилістичні, так і змістовні складові тексту уналежнюють його до художнього або нехудожнього цілого. Художній текст розуміється як «естетичний засіб опосередкованої комунікації, мета якої $\epsilon$ зображально-виразне розкриття теми, представлене в єдності форми i змісту й складається 3 мовленнєвих одиниць, що виконують комунікативну функцію» [14, с. 24]. Тобто важлива відмінність художнього тексту від нехудожнього полягає у тому, що художній текст «творить» світ, що зображений у ньому. На думку В. А. Кухаренко, предметний світ 
художнього тексту не існує до виникнення цього тексту, він з'являється симультанно 3 виникненням тексту. Крім того, художній текст $\epsilon$ триєдиним: в ньому невіддільно один від одного присутні форма, зміст і творець $[10$, с. 4-9]. В. П. Белянін уточнює, що у художньому тексті «будуються неіснуючі світи, які $є$ плодом авторських уявлень про дійсність та навіть поєднань в реальності непоєднуваного. В цьому випадку когнітивна й емоційна структурації «можливого світу» підпорядковується закономірностям авторської свідомості, у тому числі мовної» [3, с. 66]. Незважаючи на це, художній текст не є брехнею. Художник може прагнути до подібності життєвого матеріалу і його творчого осмислення, але не вимагає визнання його творів за дійсність, якою б великою не була схожість між об'єктом і його відображенням.

У лінгвістичній літературі не спостерігається також одностайності і стосовно виділення головних та факультативних категорій тексту. На думку одних авторів, «провідними текстовими властивостями $\epsilon$ цілісність, членованість i модальність», які «можуть бути названі основними категоріями тексту, що підпорядковують собі більш часткові його ознаки» [7]. Інші автори вважають, що «основу універсальних категорій тексту складають цілісність (план змісту) і зв'язність (план вираження), що вступають один з одним у відносини додатковості, діархії» [2]. У роботах багатьох дослідників тексту основними критеріями текстуальності вважаються саме когезія як формальна зв'язність та когерентність як змістовна зв'язність мовленнєвого твору [15].

Отже, Наявність у лінгвістиці різних підходів до дослідження тексту дозволяє трактувати текст як продукт мисленнєво-мовленнєвої діяльності, як мовленнєву реалізацію авторського задуму та комунікативну одиницю найвищого рівня, реалізовану як в письмовому, так і в усному мовленні.

\section{Література:}

1. Анисимова Е.Е. Паралингвистика и текст (к проблеме креолизованных и гибридных текстов). Вопросы языкознания. 1992. Вып. 1. С. 71-79.

2. Бабенко Л.Г. Лингвистический анализ художественного текста. Москва, 2008. 496 с.

3. Белянин В.П. Введение в психолингвистику. Москва, 2001. 128 с.

4. Белянин В.П. Психолингвистические аспекты художественного текста. Москва, 1988. 120 с.

5. Богин Г.И. Интерпретация как средство выведения к более широкому пониманию. URL: http://university.tversu.ru/ (дата звернення 20.10.2020).

6. Гальперин И.Р. Текст как объект лингвистического исследования. Москва, 2007. 144 с.

7. Ільєнко С.Г. Русистика. Санкт-Петербург, 2003. 366 с. 
8. Козлов Е.В. Комикс как явление лингвокультуры: знак-текст-миф. Волгоград, 2002. 220 с.

9. Кубрякова Е.С. О тексте и критериях его определения. Текст. Структура и семантика. Москва: Наука, 2001. Т. 1. С. 72-81.

10. Кухаренко В.А. Интерпретация текста. Одесса, 2002. 288 с.

11. Лотман Ю.М. Миф - имя - культура. Труды по знаковым системам. Тарту: Тартуский ун-т, 1973. T. IV. С. 282-303.

12. Николаева Т.М. Лингвистика текста. Современное состояние и перспективы (Вступ. статья). Новое в зарубежсной лингвистике. Сер.: Лингвистика текста. 1978. Вып. 8. С. 6-14.

13. Тураева 3.Я. Лингвистика текста (Текст: структура и семантика). Москва, 1986. $127 \mathrm{c}$.

14. Чернухина И.Я. Очерк стилистики художественного прозаического текста. Воронеж, 1977. 207 c.

15. Beaugrande, D.R.-A. de. \& Dressler, W. Einführung in die Textlinguistik. Tübingen, 1981. $290 \mathrm{p}$.

DOI https://doi.org/10.30525/978-9934-588-90-7-42

\title{
ДІССЛОВО “FАIRЕ” У ТВОРЕННІ ТЕРМІНІВ ФУТБОЛУ ФРАНЦУЗЬКОЇ МОВИ
}

\author{
Романчук О. В. \\ кандидат філологічних наук, доиент, \\ завідувач кафедри української та іноземних мов \\ Львівський державний університет фізичної культури \\ імені Івана Боберського \\ м. Львів, Україна \\ Коваль Р. С. \\ кандидат філологічних наук, \\ доцент кафедри украӥнської та іноземних мов \\ Львівський державний університет фізичної культури \\ імені Івана Боберського \\ м. Львів, Украӥна
}

Сьогодні футбольна лексика знаходиться у сфері наукових досліджень провідних українських та зарубіжних науковців, що підтверджено, зокрема, низкою відповідних перекладних словників, що вийшли друком в Україні [5] та за їі межами [8; 9]. 